\title{
ACÉL ÉS SZINTETIKUS SZÁLAK ORIENTÁCIÓJÁNAK MEGHATÁROZÁSA SZÁLERÖSÍTÉSŰ BETONBAN
}

\author{
JUHÁSZ KÁROLY PÉTER \\ laborvezetö. BME Szilárdságtani és Tartószerkezeti Tanszék, \\ 1111 Budapest, Müegyetem rkp. 1-3. K. II. 61. \\ Tel.: (+36-1) 463-1317. Fax: (+36-1) 463-1773. E-mail: juhasz@szt.bme.hu
}

\begin{abstract}
Mind az acél, mind a szintetikus szálerősítésủ betonok elterjedése és használata az iparban folyamatosan igényli a számítási módszerek fejlesztését. Az egységnyi keresztmetszeten áthaladó szálak darabszáma egy fontos paraméter: egyrészt jól jellemzi a szálak hatékonyságát, másrészt a próbatest eltört keresztmetszetén levő szálak megszámolásával a szálak elkeveredésének egyenletességét vizsgálhatjuk vagy az eredmények szórását csökkenthetjük. A legtöbb anyagmodell kiinduló paramétere ezért az egységnyi keresztmetszeten áthaladó szálak darabszáma.

A szálerösítésủ betonban elhelyezkedő szálaknál feltételezzük az egyenletes, homogén elkeveredést és a véletlenszerủ orientációt. Ez az orientáció azonban a zsaluzat közelében megváltozik, a szálak részben irányítottá válnak, ami hatással van az egységnyi keresztmetszeten áthaladó szálak darabszámára is. Ezen darabszámok megállapítása már a szálerősítésű beton kezdeti vizsgálatakor is foglalkoztatta a kutatókat, ennek megállapítására elméleti, szemi-empirikus és empirikus képletek egyaránt léteznek az irodalomban. Jelen cikkben az orientáció változását vizsgálom a zsaluzat közelében és különbséget teszek merev (acél) és hajlékony (szintetikus) szálak között. A keresztmetszeten áthaladó szálak darabszámára mutatok be olyan számítási módszereket, amelyek a zsaluhatást és a szálak merevségét is figyelembe tudják venni.
\end{abstract}

Kulcsszavak: szálerősítésủ beton, acél és szintetikus szálak, keresztmetszeten áthaladó szálak

\section{BEVEZETÉS}

A szálerősítésủ betonok használatának kezdetét 1874-re tehetjük, amikor Achille Berard (USA, California) szabadalmat adott be betonok tulajdonságainak szabálytalan acél hulladékkal való javítására (Maidl 1995). Az első tudományos kutatások ugyancsak Amerikából származnak, amikor Romualdi és Batson (Romualdi-Batson 1963), illetve Romualdi és Mandel (Romualdi-Mandel 1964) kísérletekkel vizsgálták az acélszál erősítésü beton viselkedését. Egyenletes eloszlás feltételezésével, valószínűségszámítás segítségével határozta meg a keresztmetszeten áthaladó szálak darabszámát Naaman 1972-ben (Naaman 1972) a doktori disszertációjában. Empirikus eredmények alapján adott számítási módszert Krenchel (Krenchel 1975), aki bevezette az elkevert szálak jellemzésére az orientációs faktort, ami a szálerősítésủ anyagmodellek alapjává vált. Ennek meghatározásával foglalkozott többek között Soroushian és Lee (Soroushian-Lee 1990), Ng, Foster és Htut (Ng-Foster-Htut 2012), Lee, Cho és Vecchio (Lee-Cho-Vecchio 2011) és Dupont és Vandewalle (Dupont-Vandewalle 2005). 
A szálak orientációja a zsaluzat közelében megváltozik, ezzel az orientációs faktor is, ami pedig az egységnyi keresztmetszeten áthaladó szálak darabszámára van hatással. Ezt a szakirodalom wall-effectnek, magyarul zsaluhatásnak nevezi. Az irodalomban jellemzően négyszög keresztmetszetü gerendát vizsgálnak, melyek esetén a zsaluhatás a széleken (egy zsalu) és a sarkokon (két zsalu) lép fel. Dupont és Vandewalle (Dupont-Vandewalle 2005) és Stroven (Stroven 2010) foglalkozott a zsaluhatás orientációs tényezőre gyakorolt hatásával acélszálak esetében. Zerbino (Zerbino et al. 2012) acélszál erősítésü öntömörödő beton elemekben: lemezben, falban és gerendában vizsgálta az acélszálak elhelyezkedését, hasonlóan Sarmientohoz (Sarmiento et al. 2012), aki gerendákban levő acélszálak kísérleti eredményeit vetette össze a számított értékekkel. Szintetikus szálak esetén a zsaluhatás más: míg az acélszálak a zsaluval való érintkezés során elfordulnak, addig a szintetikus szálak elhajlanak. Ezt a hatást Oh, Kim és Choi (Oh-Kim-Choi 2007) szintetikus szálerösítésü gerendák vizsgálata során nem vette figyelembe, azonban Alberti (AlbertiEnfedaque-Gálvez 2017) már ajánlást tett a szálak hajlékonyságának a modellezés során való figyelembevételére.

A magyar szakirodalomban az acélszálak szálorientációjával Fekete Tibor (Fekete 1973), Palotás László (Palotás 1975) és Szabó Iván (Szabó 1976) foglalkozott. Míg Fekete és Szabó véletlen száleloszlásból indult ki, addig Palotás a kísérleti eredményei alapján a bedolgozás módjától függően vette figyelembe az orientációkat.

Jelen cikkemben bemutatom a különböző módszereket, melyek segítségével a keresztmetszeten áthaladó szálak darabszáma meghatározható. Vizsgálom a zsaluhatást és az orientációs faktor megváltozását, illetve különbséget teszek merev (acél) és hajlékony (szintetikus) szálak között. Számítási módszereket mutatok be az orientációs faktor meghatározására, amely segítségével a keresztmetszeten áthaladó szálak darabszáma meghatározható. Az eredményeimet kísérleti eredményekkel hasonlítom össze.

\section{EGYSÉGNYI FELÜLETEN ÁTHALADÓ SZÁLAK DARABSZÁMÁNAK A MEGHATÁROZÁSA}

Az egységnyi keresztmetszeten áthaladó szálak darabszáma az alapja a legtöbb, a szálakat diszkréten figyelembe vevő anyagmodelleknek, mint például a Variable Engagement Modell (Voo-Foster 2003) és a Diverse Embedment Model (Lee-ChoVecchio 2011). A kísérletek kiértékelésénél ugyancsak fontos paraméter a szálak elhelyezkedése, amelyből egyrészt az elkeveredés minőségére következtethetünk (Dupont-Vandewalle 2005), másrészt a kapott eredmények kiértékelésénél a véletlen elkeveredés hatását figyelembe vehetjük (Juhász 2013, 2015). Számos kutató vizsgálta az elkeveredés kísérleti eredményekre tett hatását különböző típusú elemeken (Zerbino et al. 2012; Sarmiento et al. 2012). A fentiekből következik, hogy szálerösítésü beton vizsgálatakor az egységnyi keresztmetszeten áthaladó szálak darabszámának az ismerete több szempontból is alapvető fontosságú. 
Romualdi és Mandel levezetése (Romualdi-Mandel 1964)

Egy origó középpontú, $\alpha$ és $\gamma$ polárkoordinátákkal megadott orientációjú szál (1.a) ábra) $x$ tengelyre vett vetületének hossza:

$$
l_{\mathrm{f}, \mathrm{x}}=l_{\mathrm{f}} \cos \alpha \cos \gamma
$$

ahol $l_{\mathrm{f}}$ a szál hossza.

Ezek alapján egy adott középpontú, $l_{\mathrm{f}}$ hosszúságú szál $x$ irányú vetületi hosszának átlagértéke, $\alpha$ és $\gamma$ egyenletes eloszlása mellett:

$$
l_{\mathrm{f}, \mathrm{x}, \mathrm{m}, 1}=\frac{\int_{0}^{\frac{\pi}{2}} \int_{0}^{\frac{\pi}{2}} l_{\mathrm{f}} \cos \alpha \cos \gamma d \alpha d \gamma}{\left(\frac{\pi}{2}\right)^{2}}=0,405 l_{\mathrm{f}} .
$$

A kutatók a szálak középpontjának átlagos távolságából vezették le az egységnyi keresztmetszeten áthaladó szálak darabszámát. Romualdi és Mandel alapján ez a következő alakban írható fel:

$$
n=\frac{l_{\mathrm{f}, \mathrm{m}, \mathrm{m}} N}{V}=0,405 l_{\mathrm{f}} \frac{N}{V},
$$

ahol $n$ az egységnyi keresztmetszeten áthaladó szálak darabszáma $\left[\mathrm{db} / \mathrm{m}^{2}\right], N$ pedig a $V$ térfogatrészben levő szálak darabszáma.
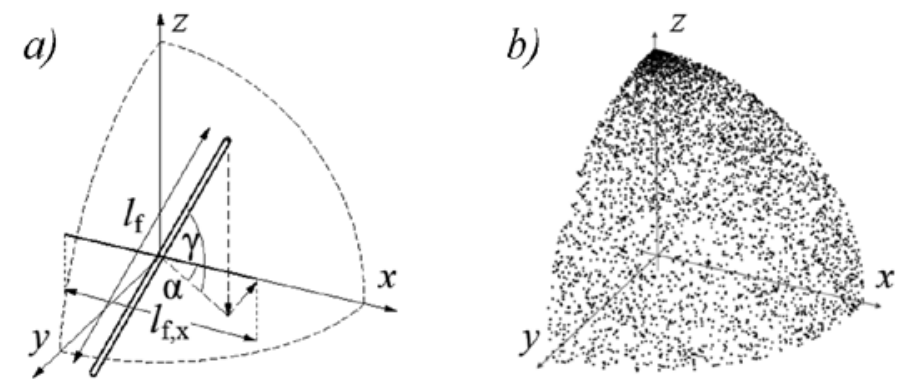

1. ábra. a) Szál orientációjának megadása polárkoordinátákkal: $\alpha$ és $\gamma ; b$ ) Véletlenszerü $\alpha$ és $\gamma$ orientációval megadott szálak végpontjai

Egyenletes eloszlású $\alpha$ és $\gamma$ értékek esetén sürüsödés tapasztalható a $z$ tengely irányában (1.b) ábra). Ez a sürüsödés kiküszöbölhető, ha a $\gamma$ szög helyett a szál végpontjának magasságát adjuk meg a 2. ábra szerint. 

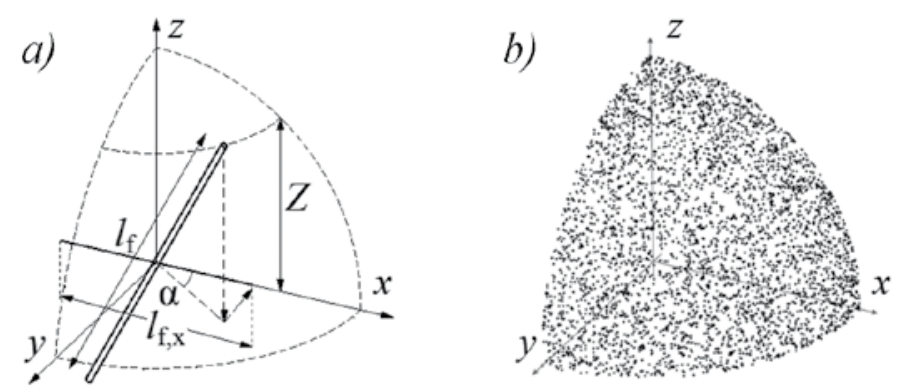

2. ábra. a) Szál orientációjának megadása $\alpha$ és $Z$ paraméterekkel; b) Véletlenszerủ $\alpha$ és $Z$ orientációval megadott szálak végpontjai

Ekkor a szálak $x$ irányú átlaghossza a következőképpen módosul $\alpha$ és $Z$ egyenletes eloszlása mellett:

$$
l_{\mathrm{f}, \mathrm{m}, \mathrm{m}, 2}=\frac{\int_{0}^{\frac{\pi}{2}} \int_{\mathrm{f}} l_{\mathrm{f}} \cos \alpha \cos \left(\arcsin \frac{Z}{l_{\mathrm{f}}}\right) d Z d \alpha}{\frac{\pi}{2} l_{\mathrm{f}}}=0,5 l_{\mathrm{f}} .
$$

Annak érdekében, hogy egyenletes legyen az eloszlás módosítani kell Romualdi és Mandel képletét, így az egységnyi keresztmetszeten áthaladó szálak darabszáma a következő lesz:

$$
n=\frac{N}{V} 0,5 l_{\mathrm{f}}
$$

\section{Naaman levezetése (Naaman 1972)}

Naaman a keresztmetszeten áthaladó szálak darabszámát valószínűségszámítás segítségével határozta meg. Vegyünk egy szálat, amely középpontja az $x$ tengelyen helyezkedik el (3. ábra).

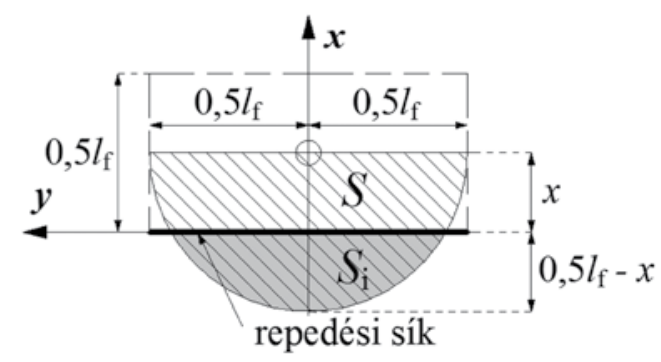

3. ábra. Szál repedési sík átdöfésének valószínűsége 
Ha a szál középpontja a repedési síktól $0,5 l_{\mathrm{f}}$ értéknél kisebb távolságra helyezkedik el, akkor a szál átdöfheti a repedési síkot. Ennek valószínűsége a szál középpontja köré rajzolt $S_{\mathrm{i}}$ és $S$ felületü gömbszelet felületének a hányadosa (3. ábra):

$$
q_{\text {Naaman }}=\frac{S_{\mathrm{i}}}{S}=\frac{0,5 l_{\mathrm{f}}-x}{0,5 l_{\mathrm{f}}}=1-\frac{2 x}{l_{\mathrm{f}}} .
$$

A repedési keresztmetszet mindkét oldalán egységnyi térfogattal számolva, az egységnyi keresztmetszeten áthaladó szálak száma hasonlóan Romualdi és Mandel módosított képletéhez (5):

$$
n=2 \int_{0}^{\frac{l_{\mathrm{f}}}{2}}\left(1-\frac{2 x}{l_{\mathrm{f}}}\right) \frac{N}{V} d x=\frac{N}{V} 2 \int_{0}^{\frac{l_{\mathrm{f}}}{2}}\left(1-\frac{2 x}{l_{\mathrm{f}}}\right) d x=\frac{N}{V} 0,5 l_{\mathrm{f}} .
$$

Krenchel orientációs faktora (Krenchel 1975)

Ideális állapotot feltételezve a szálak mindegyike párhuzamos a repedés normálisával, azaz jelen esetben mindegyik szál $x$ irányban áll. Vegyük a szálak térfogatrészét: $V_{\mathrm{f}}$ (szálak tömege a betonban $\left[\mathrm{kg} / \mathrm{m}^{3}\right] /$ szálak térfogatsúlya $\left[\mathrm{kg} / \mathrm{m}^{3}\right]$ ), illetve egy elemi szál keresztmetszeti területét: $A_{\mathrm{f}}$. Ebben az esetben a szálak $A$ keresztmetszeten áthaladó szálak darabszáma a következő képlettel írható fel:

$$
n_{\mathrm{i}}=\frac{V_{\mathrm{f}}}{A_{\mathrm{f}}} A,
$$

ahol $n_{\mathrm{i}}$ az ideális darabszámot jelenti [db] az $A$ keresztmetszeten.

Mivel a valóságban a szálak orientációja nem ideális, így Krenchel a következő képlettel vezette be az orientációs faktort:

$$
\theta_{\text {Krenchel }}=\frac{n_{\mathrm{a}}}{n_{\mathrm{i}}}=n_{\mathrm{a}} \frac{A_{\mathrm{f}}}{V_{\mathrm{f}} A},
$$

ahol $n_{\mathrm{a}}$ az $A$ keresztmetszeten áthaladó szálak darabszáma [db], kísérlet útján az eltört felületen történő megszámlálással meghatározva.

Belátható, hogy Krenchel orientációs faktora nem más, mint Romualdi-Mandel és Naaman levezetésében a szálhosszat módosító tényező, amely egyenletes eloszlás feltételezésével 0,5 volt.

\section{ZSALUHATÁS}

A zsaluzat orientációt befolyásoló hatása különböző merev és hajlékony szálak esetén, hiszen a különböző anyagú szálak máshogy viselkednek a zsaluval történő érintkezéskor. Ezt a különböző viselkedést mutatom meg és hatását a keresztmetszeten áthaladó szálak darabszámára. 


\subsection{ZSALUHATÁS MEREV (ACÉL) SZÁLAK ESETÉN}

Dupont és Vandewalle modellje acélszálakra (Dupont-Vandewalle 2005)

A kutatók egy négyszög keresztmetszetü gerendát a zsaluzat hatását tekintve három típusú részre osztották fel: 1: zavartalan zóna, 2: zavart zóna - egy zsaluzat, 3: zavart zóna - két zsaluzat (4. ábra).

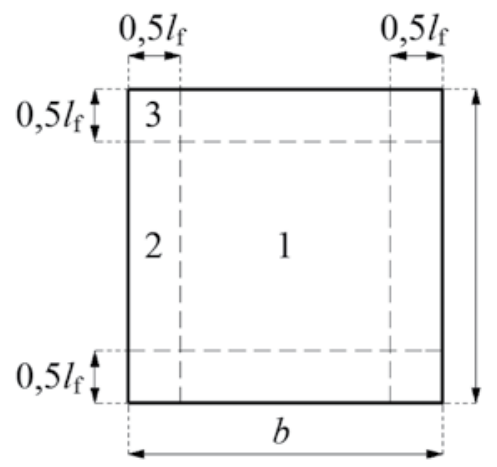

4. ábra. Keresztmetszeti zónák (Dupont-Vandewalle 2005)

Feltételezték, hogy zsalu közelében a szálak középpontjai nem változnak, nem tolódnak el, eloszlásuk egyenletes marad, azonban a zsaluval érintkező szálak elfordulnak a szál középpontja körül, úgy, hogy érintkezzen a zsaluval. Ez azokra a szálakra igaz, amelyek középpontja a zsaluzathoz $0,5 l_{\mathrm{f}}$ távolságnál közelebb van. Ezeket a szálakat különböző orientációs faktorokkal vették figyelembe, majd Krenchel képlete (8) alapján meghatározták a keresztmetszeten áthaladó szálak darabszámát.

Romualdi és Mandel (5), illetve Krenchel képlete (8) is abból a feltételből indul ki, hogy a szálak a törési keresztmetszetre nézve merőleges irányúak, majd a tényleges szálhossz helyett egy módosított értékkel számolnak, előző az effektív szálhoszszal, utóbbi az orientációs tényezővel módosított szálhosszal. Mindkét kutató hasonló eredményre jutott. Követve ezt a modellt valóban csak azokat a szálakat érinti a zsaluhatás, amelyek érintkezni tudnak a zsaluval, azaz a szál középpontja $0,5 l_{\mathrm{f}}$ távolságnál közelebb van a zsaluzathoz.

\section{Javasolt modell}

Visszatérve Naaman levezetésre, vizsgáljuk meg mi történik, ha egy oldalról véges térben vizsgáljuk a szálakat. Vegyünk egy $0,5 l_{\mathrm{f}}$ szélességü, $0,5 l_{\mathrm{f}}$ vastagságú és $z$ irányban végtelen hosszúságú térrészt, legyen a jele $T_{1}$, amelyben levő szálak az $A_{1}$ oldallappal való átdöfésének a valószínüségét vizsgáljuk az 5. ábra szerint. Ebben a $T_{1}$ térrészben helyezkednek el a szálak középpontjai, az origót az oldallap szélén 
vegyük fel. Egy szál, mely középpontjának koordinátái $x$ és $y$, az $A_{1}$ oldallappal való döfésének a valószínüsége a következő:

$$
\theta(x, y)=\frac{S_{\mathrm{i}}(x)-\left(S_{\mathrm{n}, 1}(x, y)+S_{\mathrm{n}, 2}(x, y)\right)}{S},
$$

ahol $S_{\mathrm{n}, 1}$ és $S_{\mathrm{n}, 2}$ a keresztmetszet síkján áthaladó, de a keresztmetszetet nem döfö szálakhoz tartozó felület az 5.a) ábra szerint. Vegyünk két szomszédos, a $T_{1}$ térrésszel azonos méretü $T_{2 \mathrm{a}}$ és $T_{2 \mathrm{~b}}$ térrészeket. Ezekben található $\left(x ; 0,5 l_{\mathrm{f}}+y\right)$ és $(\mathrm{x} ;-\mathrm{y})$ középpontú szálaknak a $T_{1}$ térfogatrészbe átnyúló szálaihoz tartozó felületei ugyancsak rendre $S_{\mathrm{n}, 1}$ és $S_{\mathrm{n}, 2}$ lenne, ahogy az 5.b) ábrán látható.
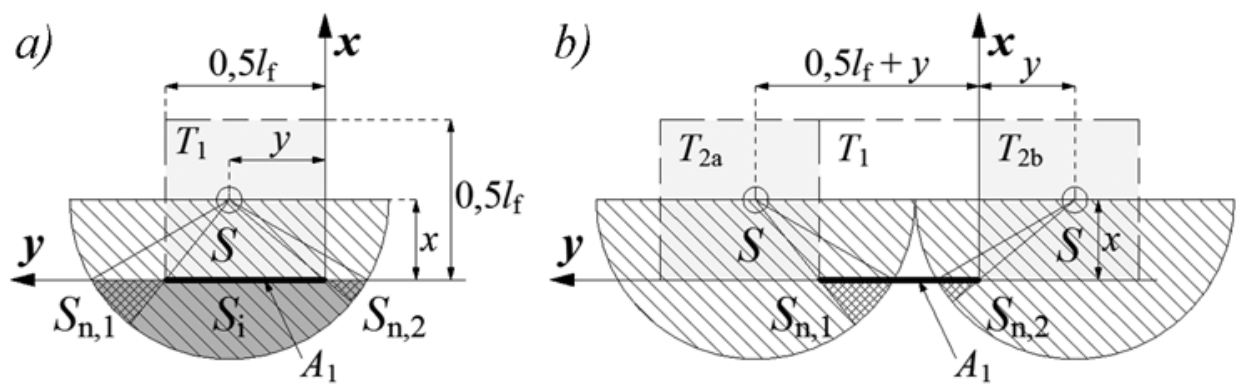

5. ábra. a) $T_{1}$ térrészből az $A_{1}$ oldallapon áthaladó szálak értelmezése b) Áthatás a szomszédos $T_{2 \mathrm{a}}$ és $T_{2 \mathrm{~b}}$ térrészből

$T_{1}$ térrészben levő szálak esetén adott $y$ értéknél a döfés valószínűsége:

$$
\theta(y)=2 \int_{0}^{0,5 l_{\mathrm{f}}} \frac{S_{\mathrm{i}}(x)-\left(S_{\mathrm{n}, 1}(x, y)+S_{\mathrm{n}, 2}(x, y)\right)}{S} d x,
$$

illetve $T_{2 \mathrm{a}}$ és $T_{2 \mathrm{~b}}$ térrészben levő szálak esetén adott $y$ értéknél a döfés valószínüsége:

$$
\theta(y)=2 \int_{0}^{0,5 L_{\mathrm{t}}} \frac{S_{\mathrm{n}, \mathrm{i}}(x, y)}{S} d x .
$$

Adott $y$ középponti koordinátájú szálak $A_{1}$ oldallapot való döfésnek a valószínüségét ábrázoljuk a 6. ábrán.

Láthatjuk, hogy a $T_{1}$ térrészben az $A_{1}$ oldallap közepétől távolodva az oldallap széléig a valószínüség csökken, ahogy az $S_{\mathrm{n}, 1}+S_{\mathrm{n}, 2}$ összege növekszik, illetve a $T_{2}$ térrészekben is csökken a valószínüség az $A_{1}$ oldallap szélétől távolodva. Az $A_{1}$ oldallaphoz tartozó görbe alatti terület legyen $P_{1}$, a görbe felett 0,50 értékig kiegészítő terület legyen $P_{3}$. A $T_{1}$ térrészben levő szálak $A_{1}$ keresztmetszettel való döfésének a valószínüsége tehát a görbe átlagértéke: 


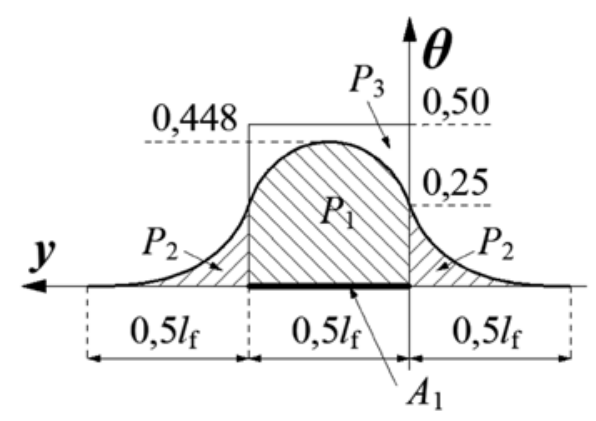

6. ábra. Szálak döfésének valószínűsége

$$
\theta_{T_{1}}=\frac{P_{1}}{0,5 l_{\mathrm{f}}}=0,394 .
$$

Azonban az $A_{1}$ keresztmetszetet a szomszédos $T_{2 \mathrm{a}}$ és $T_{2 \mathrm{~b}}$ térrészekböl is átdöfhetik szálak. Ezen görbe alatti terület legyen $P_{2}$. Az integrálást elvégezve megkapjuk, hogy $2 P_{2}=P_{3}$, azaz ha a szomszédos $T_{2 \mathrm{a}}$ és $T_{2 \mathrm{~b}}$ térrészekböl átnyúló szálak döféseit is figyelembe vesszük, akkor a következöt kapjuk:

$$
\theta_{T_{1}: T_{2 a}-T_{2 b}}=\frac{P_{1}+2 P_{2}}{0,5 l_{\mathrm{f}}}=0,50,
$$

ami megegyezik Naaman végtelen térre levezetett értékével (7).

Vizsgáljuk meg, hogy mi történik akkor, ha a $T_{1}$ térrész melletti szomszédos, azonos méretü $T_{3}$ térrész határán zsalu van, ahogy a 7.a) ábrán látható. Ebben a térrészben levő szálak a zsaluval érintkezhetnek, azaz a zsaluzat hatással lehet az orientációjukra. Az orientáció megváltozása miatt a $T_{3}$ térrészben levő szálak átnyúlása a $T_{1}$ térrészbe korlátozva van, kevesebb szál tudja döfni az $A_{1}$ oldallapot. Három jól elkülöníthető részre bontható a $T_{3}$ térrész. Ha a szál középpontja az $I$. mezőben van, akkor nem döfi át az $A_{1}$ oldallapot, ha a II. mezöben van, akkor átdöfi, de a zsaluhatás miatt csak kevesebb szál, mint zsalu nélkül, a III. mezőben levő középpontú szálakra pedig nem érvényesül a zsaluhatás. Ezen mezők magyarázata és szemléltetése a 7.c) ábrán látható.

Az I., II. és III. mezöt definiáló görbék helyett használjuk az egyenesekkel definiált $I V$. mezőt, és tételezzük fel, hogy az itt levő szálak minden esetben átnyúlhatnak a $T_{1}$ térrészbe és döfhetik az $A_{1}$ oldallapot (7.a) ábra). Ebben az esetben a döfés valószínüsége:

$$
\theta(y)=2 \int_{I V} \frac{S_{\mathrm{w}, \mathrm{V}}(x, y)}{S_{T 3}(x, y)} d x .
$$



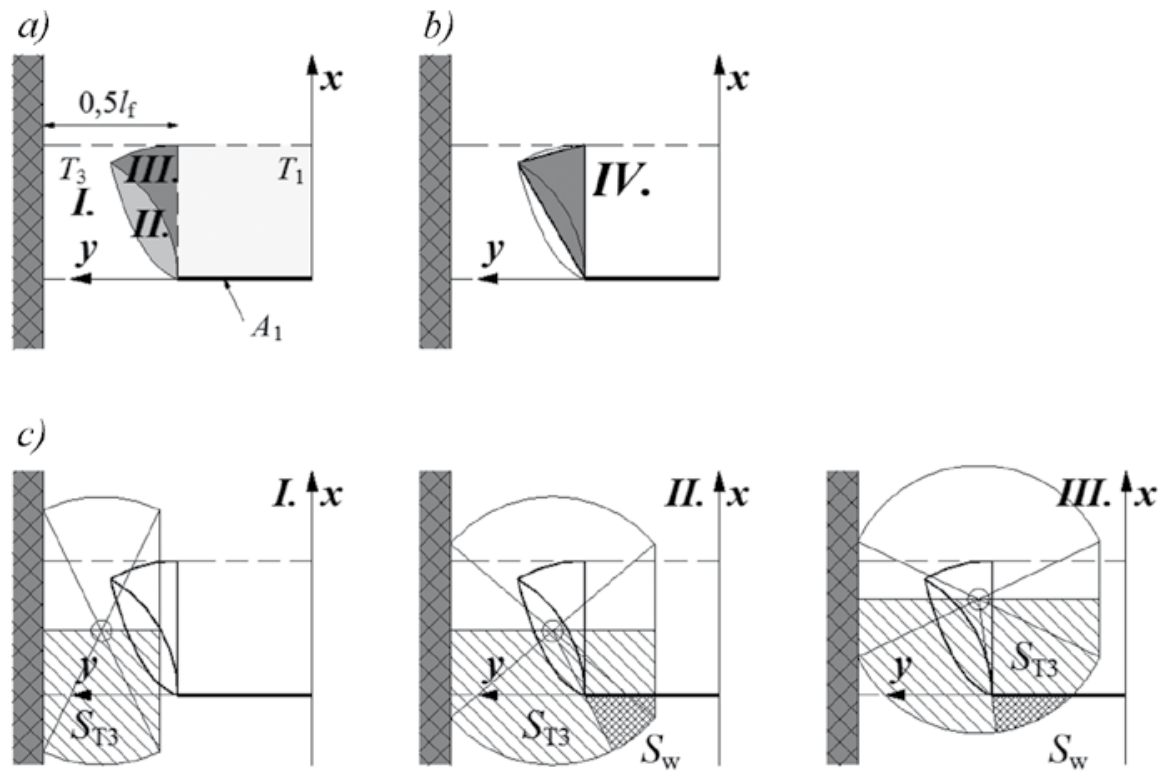

7. ábra. a) Zsaluhatás érvényesülése $0,5 l_{\mathrm{f}}-l_{\mathrm{f}}$ távolságban, $I, I I$ és $I I I$ térrész definiálása b) $I V$ egyszerüsített térrész c) $I, I I$ és $I I I$ térrészek magyarázata

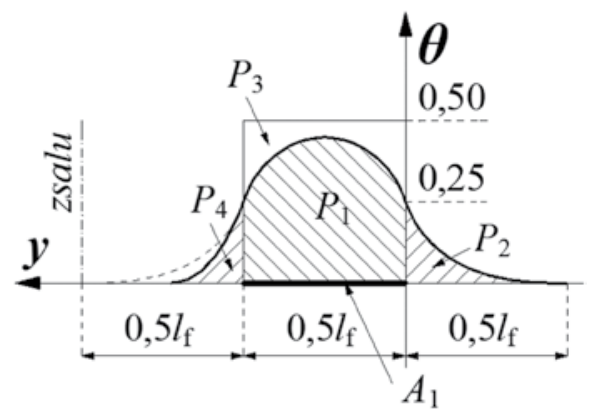

8. ábra. $A_{1}$ oldallap döfésének valószínűsége egy oldalról folyamatos térrész, egy oldalról zsaluhatással érintett térrész esetén

Ábrázoljuk a valószínüségeket az $y$ tengely mentén (8. ábra).

A $T_{1}$ térrészben levő szálak $A_{1}$ keresztmetszettel való döfésének a valószínüsége, figyelembe véve a szomszédos $T_{2}$ zsaluhatás nélküli, illetve a másik oldalról a $T_{3}$ zsaluhatással érintett térrészt a következőképp írható fel:

$$
\theta_{T_{1}: T_{3}-T_{2}}=\frac{P_{1}+P_{2}+P_{4}}{0,5 l_{\mathrm{f}}}=0,479 .
$$




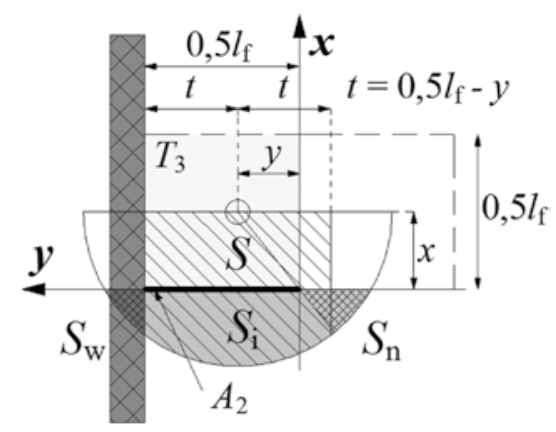

9. ábra. $T_{3}$ térrészben levő szálak döfése az $A_{3}$ oldallapon

A $T_{1}$ térrészben levő szálak nem tudnak érintkezni a zsaluval, azaz a zsaluzat nincs hatással az orientációjukra, csak a $T_{3}$ térrészben levőknek. Az átnyúlások korlátozása miatt azonban mégis kevesebb szál döfi az $A_{1}$ oldallapot ebben az esetben, azaz egy $k v a ́ z i$-zsaluhatásról beszélhetünk ebben az esetben.

Vizsgáljuk meg, mi történik a $T_{3}$ térrészben, ahol a zsaluzat közvetlenül hatással van a szálak orientációjára (9. ábra). Az $A_{2}$ oldallapot átdöfó szálakat az egyik oldalról a zsaluzat korlátozza, ezek az $S_{\mathrm{w}}$ felületrészhez tartozó szálak. A másik oldalon azok a szálak, amelyek nem döfik az $A_{2}$ oldallapot az $S_{\mathrm{n}}$ felületrészhez tartozó szálak. Ebben az esetben a döfés valószínüsége:

$$
\theta(y)=2 \int_{0}^{0,5 I_{\mathrm{f}}} \frac{S_{\mathrm{i}}(x)-S_{\mathrm{w}}(x, y)-S_{\mathrm{n}}(x, y)}{S(x, y)} d x .
$$

Ábrázoljuk a valószínűségeket az y tengely mentén (10. ábra).

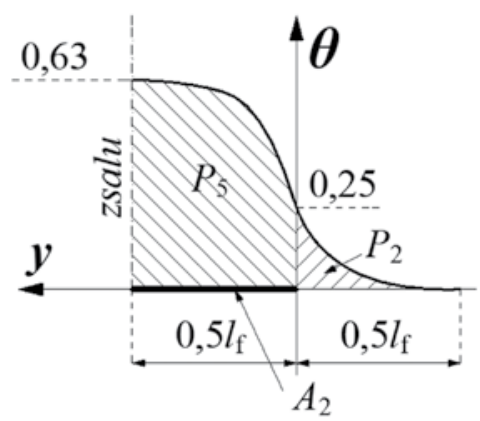

10. ábra. $A_{2}$ oldallap döfésének valószínüsége egy oldalról folyamatos térrész, másik oldalt zsaluzott felület esetén 
A $T_{3}$ térrészben levő szálak $A_{2}$ keresztmetszettel való döfésének a valószínüsége, figyelembe véve a szomszédos $T_{1}$ térrészből átnyúló szálakat is a következő:

$$
\theta_{T_{3}: z s-T_{1}}=\frac{P_{5}+P_{2}}{0,5 l_{\mathrm{f}}}=0,618 .
$$

Közvetlenül a zsalu melletti szálak orientációs faktora $\theta=2 / \pi=0,63$, amely megegyezik egy kétdimenziós, azaz síkban fekvő szál orientációs faktorával (SoroushianLee 1990; Lee-Kim 2010).

\subsection{ZSALUHATÁS HAJLÉKONY SZÁLAK ESETÉN}

Szintetikus szálak esetén feltételezzük, hogy a szálak elhajlanak a zsaluval való érintkezés során. Alberti (Alberti-Enfedaque-Gálvez 2017) ezt a szálak hosszának csökkentésével vette figyelembe, jelen cikkben ezt a szálak elhajlásával veszem figyelembe. A zsaluzat hatása ebben az esetben csak azoknál a szálaknál jelentkezik, amelyek középpontja $0,5 l_{\mathrm{f}}$ távolságnál közelebb van a zsaluzathoz. Szintetikus szálak esetében a szálak elhajlása miatt az átnyúlás nincs korlátozva, azaz a kvázi-zsaluhatás nem érvényesül (11. ábra).

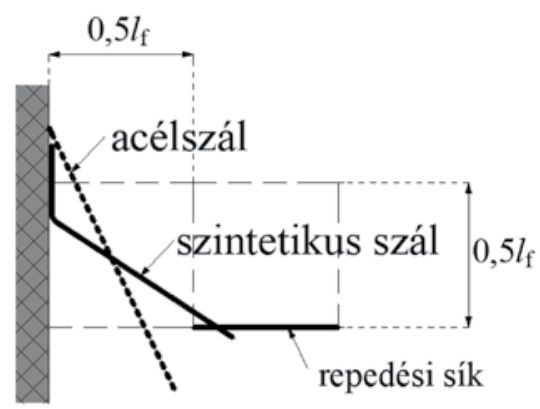

11. ábra. Acél és szintetikus szálak átnyúlása a szomszédos keresztmetszeti zónába zsaluzat hatásakor

Mivel a szálak végpontjai elhajlás során már nem gömbfelületen lesznek, így a Naaman-féle valószínüségszámítás szerinti módszer ez esetben nem használható. Ugyanakkor nem is szükséges az alkalmazása, mivel a szomszédos térrészre a zsaluzat hatása nem érvényesül. Keresztmetszeten áthaladó szálak darabszámának a megállapítására szintetikus szálak esetén így a Romualdi és Mandel-féle átlagos szálhosszból levezetett képlet (5) alkalmasabb. Ehhez először az $x$ irányú vetületek átlag hosszát kell meghatároznunk. A zsaluzattal érintkező szálak elhajlanak, $x$ irányú vetületi hosszukat a (4) képlet módosításával vesszük figyelembe: 


$$
l_{\mathrm{f}, \mathrm{x}, \mathrm{m}, 3}=\frac{\int_{0}^{\frac{\pi}{2}} \int_{0}^{W} l_{\mathrm{f}} \cos \alpha \cos \left(\arcsin \frac{Z}{l_{\mathrm{f}}}\right) d Z d \alpha+\int_{0}^{\frac{\pi}{2}} \int_{W}^{l_{\mathrm{f}}}\left[l_{\mathrm{f}} \frac{W}{Z}\left(\cos \left(\arcsin \frac{Z}{l_{\mathrm{f}}}\right)-1\right)+l_{\mathrm{f}}\right] \cos \alpha d Z d \alpha}{\frac{\pi}{2} l_{f}}
$$

ahol $W$ a szál középpontjának távolsága a zsaluzattól.

A szintetikus szálak esetében a keresztmetszeten áthaladó szálak darabszámára a zsaluhatás nem szimmetrikus, mint acélszálak esetében (12. ábra), így az $x$ irányú vetületi hosszak átlaga a következő lesz:

$$
l_{\mathrm{f}, \mathrm{x}, \mathrm{m}, 4}=\frac{l_{\mathrm{f}, \mathrm{x}, \mathrm{m}, 2}+l_{\mathrm{f}, \mathrm{x}, \mathrm{m}, 3}}{2} .
$$

A szintetikus szálak $x$ irányú vetületének átlaga a zsaluzattól való távolság függvényében a 13. ábrán látható az acélszálhoz viszonyítva.
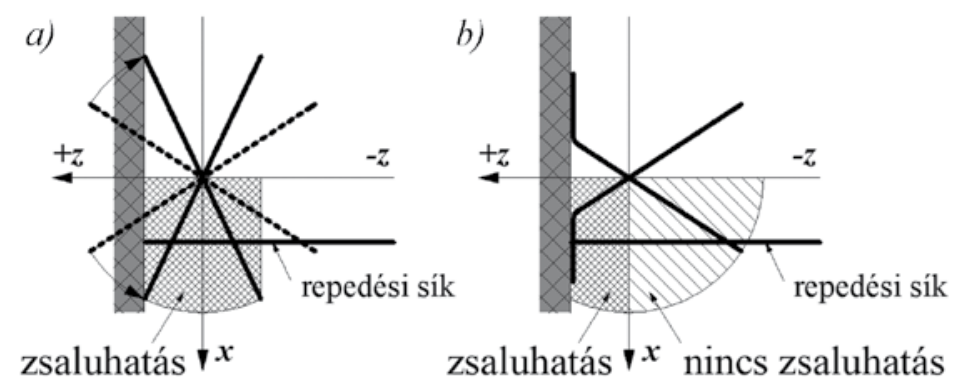

12. ábra. Zsaluzat hatása a keresztmetszeten áthaladó szálak darabszámára $a$ ) acélszálak b) szintetikus szálak esetén

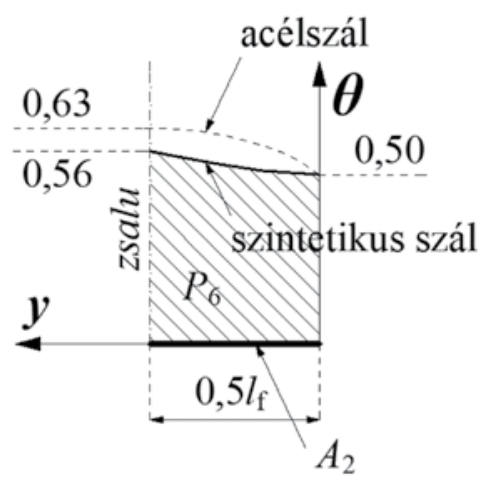

13. ábra. A szálak átlagos hossza a zsaluzattól mért távolság függvényében 
A $T_{3}$ térrészben levő szálak $A_{2}$ keresztmetszettel való döfésének a valószínűsége tehát szintetikus (hajlékony) szálak esetén:

$$
\theta_{T_{3}: z s}=\frac{P_{6}}{0,5 l_{\mathrm{f}}}=0,53 .
$$

\subsection{EREDMÉNYEK}

Dupont és Vandewalle orientációs faktorait (14.a) ábra) továbbfejlesztettem, megmutatva, hogy az alapjában háromféle zónán kívül a zsaluzat hatása a keresztmetszet mélyebb részeibe is benyúlik. Két zsaluzat hatását nem vizsgáltam, itt az eredeti ajánlást változatlanul hagytam. A 14.b) ábrán szürke színnel jelöltem azokat a zónákat, amelyek vizsgálata további kutatást igényelnek, ahol a kétoldali zsaluhatás jelentkezhet.

Szintetikus szálak esetén megmutattam, hogy a szálak elhajlásai miatt nem befolyásolják a szomszédos térrészeket, ezért a zsaluzat hatása csak $0,5 l_{\mathrm{f}}$ távolságban érvényesül (14.c) ábra). Itt viszont a szálak nem elfordulnak, hanem elhajlanak. Levezettem az elhajló szálak $x$ tengelyre vett vetületeinek átlagát, amelyből az orientációs faktor származtatható. Sarkokat nem vizsgáltam, értéke valamivel kisebb lesz, mint acélszálak esetében.

Acélszálak esetén Dupont és Vandewalle zónái, jelen kutatás alapján módosított zónák, illetve szintetikus szálak esetén a zónák és a hozzájuk tartozó orientációs faktorok a 14. ábrán szerepelnek.

a) b) c)

Acélszálak

Dupont-Vandewalle
Acélszálak

Módosított

\section{Szintetikus szálak}

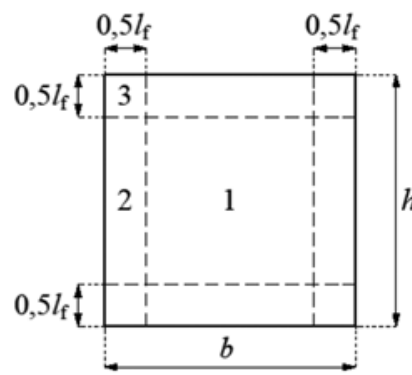

1: 0,50

2: 0,60

3: 0,84

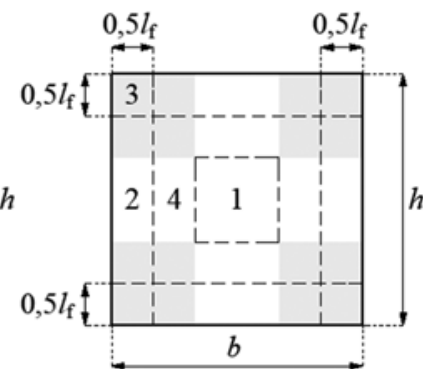

1: 0,50

2: 0,618

3: 0,84

4: $\mathbf{0 , 4 7 9}$

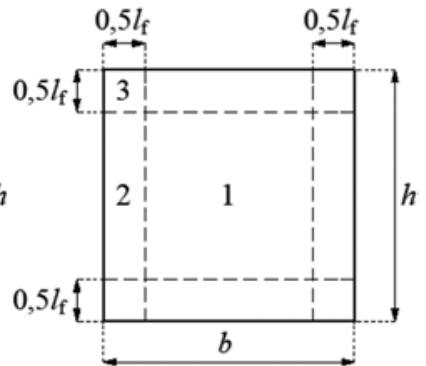

1: 0,50

2: $\mathbf{0 , 5 3}$

3: $<0,84$

14. ábra. Keresztmetszeti zónák és orientációs faktorai 


\section{VERIFIKÁLÁS}

Dupont és Vandewalle az eredményeket különböző hosszúságú acélszálakkal készített gerendákon verifikálta. A kísérlet után megszámolták az eltört keresztmetszeteken áthaladó szálak darabszámát, és ezt hasonlították össze az orientációs faktorok segítségével kiszámított darabszámokkal. A kísérletek során a megszámolt szálak darabszámának az átlagértékét igen pontosan meg tudták határozni, ugyanakkor a variációs koefficiens relatív magas: $36 \%$ volt. A zónákat külön nem vizsgálta, csak az eltört keresztmetszeten található szálak darabszámát hasonlította össze a modell eredményeivel. A módosított zónáknál a 2-es zónában levő orientációs faktornál magasabb értéket kaptam: 0,60 helyett 0,618 , viszont az 1-es zóna a 4-es zóna miatt módosult: az orientációs faktor 0,5-röl 0,479-re csökkent. A teljes keresztmetszetre vizsgálva az áthaladó szálak darabszámát 20 és $70 \mathrm{~mm}$ közötti hosszúságú szálak esetében az eltérés $0,5 \%$ alatt van a két modellben. A modell tehát nem összességében változtatja meg a szálak mennyiségét, hanem csak a lehetséges eloszlásukat módosítja.

Kísérletemben 7 darab szabványos méretü $(150 \times 150$ keresztmetszetü, $550 \mathrm{~mm}$ hosszú), középen $25 \mathrm{~mm}$ mélyen bevágott acél szálerösítésủ gerendát vizsgáltam meg, melynek az eltört keresztmetszete a bevágás felett $125 \times 150 \mathrm{~mm}$ volt. A száladagolás $55 \mathrm{~kg} / \mathrm{m}^{3}$ volt. A gerendák eltört felületén a 14.a) ábra szerinti mezökben meghatároztam a keresztmetszeten áthaladó szálak átlag darabszámát $\left[\mathrm{db} / \mathrm{cm}^{2}\right]$. Dupont és Vandewalle, valamint a módosított modell alapján meghatároztam ugyanezen zónákhoz tartozó szálak darabszámát. A módosított modellben az 1-es és 4-es mezö átlagát számoltam. Az eredmények és százalékos eltérések az 1. táblázatban szerepelnek.

Az 1-es mezőben mindkét modell alapján számított szál darabszám kis eltérést mutat a kísérleti értékhez képest, azonban a 2-es mezőben mintegy 30\%-kal túlbecslik, míg a 3-as mezőben az eltérés már több, mint 110\%. A 3-as mezőben azonban a kísérletek eredménye alapján kevesebb szál volt, mint az 1-es és 2-es mezőben. Az 1-es mezőben levő szál darabszámot a módosított modell jobban becsli, mint Dupont és Vandewalle modellje, azonban a 2-es mezőben már megfordul: a módosított modellhez képest nagyobb az eltérés. Ha a teljes keresztmetszeten áthaladó szálak darabszámát nézzük, akkor Dupont és Vandewalle 18,6\%, míg a módosított modell 18,5\%-ban tér el a kísérleti eredményektől.

1. táblázat. Egységnyi keresztmetszeten áthaladó szálak darabszáma $\left[\mathrm{db} / \mathrm{cm}^{2}\right]$, kísérleti és modell értékek összehasonlítása

\begin{tabular}{|c|c|c|c|}
\hline & Kísérleti értékek & Dupont és Vandewalle & Módosított modell \\
\hline 1. mezö & 1,0966 & $1,2031(+9,7 \%)$ & $1,1820(+7,7 \%)$ \\
\hline 2. mezö & 1,1205 & $1,4437(+28,8 \%)$ & $1,4870(+32,7 \%)$ \\
\hline 3. mezö & 0,9562 & $2,0212(+111,3 \%)$ & $2,0212(+111,3 \%)$ \\
\hline
\end{tabular}



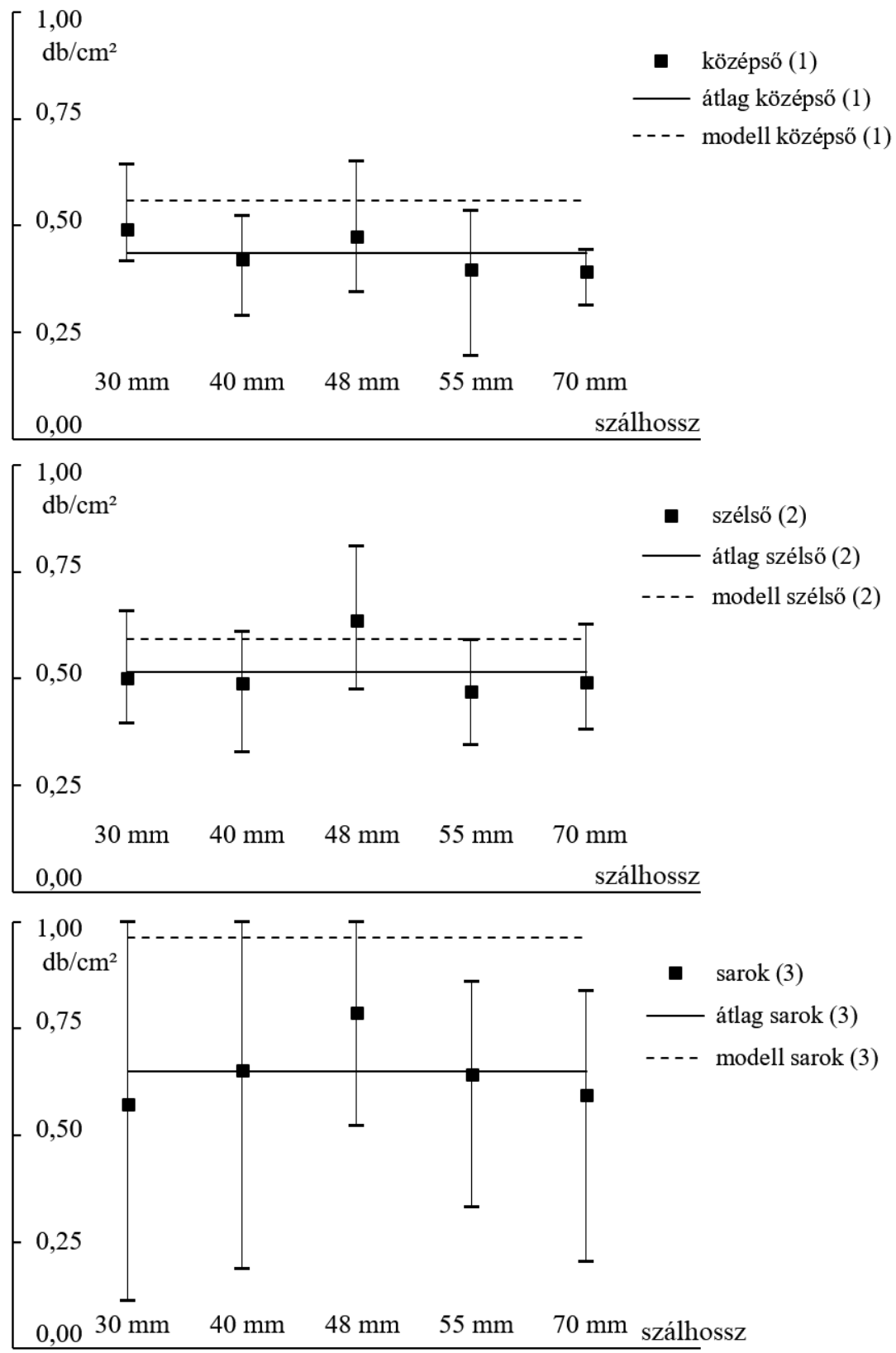

15. ábra. Keresztmetszeten áthaladó szintetikus szálak darabszáma különböző szálhosszúság esetén, (1) középső, (2) szélső és (3) sarok zónákban, különböző szálhosszúságok átlagértéke és szélső értékei, illetve a modell eredményei (Juhász-Kis 2017 alapján) 
A szintetikus szálak esetében Kis Viviennel közösen végzett kutatási eredményeinket vizsgálom (Juhász-Kis 2017), ahol különböző szálhosszúságú szintetikus szálakkal készült ugyancsak szabványos méretü gerendákat vizsgáltunk meg. A szálak hossza: 30, 40, 48, 55 és 70 mm volt. Mindegyik szálhosszal 7 darab gerendát öntöttünk azonos $4 \mathrm{~kg} / \mathrm{m}^{3}$-es adagolással. A szálakat megszámoltuk a 1-es, 2-es és 3-as zónában, a kísérleti eredmények és a modell eredményeinek az összevetése a 15. ábrán látható. A modell a középsö 1-es zónában mintegy $22 \%$-kal ad nagyobb eredményt, mint a kísérleti értékek, a szélső 2-es zónában pedig mintegy 12\%-kal. A modell felülbecsli az eredményeket mindkét zónában, de közelebbi értéket ad, mint acél esetében. A 3-as zónában az acélhoz alkalmazott értékkel számított darabszám 32\%-kal nagyobb a modell alapján. Kísérletből visszaszámolt orientációs faktor $\theta_{3}=0,581$ értéket ad.

\section{5. ÖSSZEFOGLALÁS}

A betonban való elkeveredés szempontjából az acél és a szintetikus szálak legnagyobb különbsége az elemi szálak merevsége: míg az acél szálakat merev szálaknak tekinthetjük, addig a szintetikus szálakat hajlékonynak. Jelen modell alapján a szálakat a középpontjukkal és orientációjukkal jellemezzük, egyenletes elkeveredés feltételezésével, melyből származtatjuk az eltört felületen áthaladó szálak darabszámát. A zsaluzat közelében az orientáció megváltozik, részben irányítottá válik. Ez az irányítottság más acél és szintetikus szálak esetében, így a zsaluzat közelében a keresztmetszeten áthaladó szálak darabszáma is másképp változik.

Jelen cikkben acélszálak esetén egy javasolt modellt mutatok be, amelynél bevezetem a kvázi-zsaluhatás fogalmát és megmutatom, hogy a zsaluzat hatása a keresztmetszet mélyebb részein is érvényesül. Ennek megfelelően módosítom Dupont és Vandewalle keresztmetszeti zónáit és orientációs faktorait. A modellel a keresztmetszeten áthaladó szálak darabszáma meghatározható, amelyet Dupont és Vandewalle eredményeivel, illetve saját kísérleti eredményekkel is összehasonlítok. A kísérletek során szabványos méretü, bevágott gerendákat vizsgálok, ahol az eltört keresztmetszet mérete $125 \times 150 \mathrm{~mm}$. Ezen az eltört keresztmetszeten számolom meg a szálak darabszámát és hasonlítom össze a modell eredményeivel. A kísérleti eredményektől való eltérés a zsaluhatással nem érintett részen elenyésző, zsaluhatással érintett részeknél már jelentős, a modell felülbecsli a keresztmetszeten áthaladó szálak darabszámát. Dupont és Vandewalle modelljének az eredményeitől a bemutatott modell eredményeinek eltérése nem számottevő.

Szintetikus szálak esetében a zsaluhatás másképp érvényesül, mint acélszálak esetében. Megmutatom, hogy szintetikus szálak esetében nincs kvázi-zsaluhatás, és az orientációs faktorok is más értékeket vesznek fel, köszönhetően a szálak hajlékonyságának a zsaluzattal való érintkezéskor. Szintetikus szálak esetében is megadom a keresztmetszeti zónákat és orientációs faktorokat, majd saját kísérleti eredményekkel hasonlítom össze. A kísérletek során ugyancsak szabványos méretü geren- 
dák eltört felületeit vizsgálom. A modell felülbecsli a kísérleti eredmények értékeit, de pontosabb eredményeket ad, mint acélszál estében.

A szálak elhelyezkedése és orientációja további paraméterektől is függ a betonban, melyeket jelen cikk nem vizsgál. Az adalékanyag mérete, a beton konzisztenciája és tömörítése is hatással van a szálakra. A modell pontosítása során ezeket a paramétereket is figyelembe kell venni a további kutatásoknál.

\section{KÖSZÖNETNYILVÁNÍTÁS}

Szeretnék köszönetet mondani Fehér Eszter PhD hallgatónak észrevételeiért, amelyek figyelembevétele sokat javított a dolgozaton. A kísérletekhez használt ZWICK/ ROELL Z150 típusú univerzális anyagvizsgáló gépet a TÁMOP 4.2.1/B-09/1/KMR2010-0002 pályázat biztosította.

\section{HIVATKOZÁSOK}

Alberti, M. G. - Enfedaque, A. - Gálvez, J. C.: On the prediction of the orientation factor and fibre distribution of steel and macro-synthetic fibres for fibre-reinforced concrete. Cement and Concrete Composites 77 (2017) 29-48.

Dupont, D. - Vandewalle, L.: Distribution of steel fibres in rectangular sections. Cement \& Concrete Composites 27 (2005) 391-398.

Fekete T.: Acélszálerősítésủ betonszerkezetek szilárdsági vizsgálata. BME Közlekedésmérnöki Kar Mechanika Tanszék tanulmánya, 1973.

Juhász K. P.: Szintetikus makro szálerősítésű beton gerendavizsgálatok kiértékelése a valós száleloszlás vizsgálata alapján. Anyagvizsgálók lapja (2013) 3-4. 93-97.

Juhász K. P.: Evaluation of fibre reinforced concrete beam test results based on the examination of the real fibre distribution. In: Fibre Concrete 2015. Eds: A. Kohoutková et al. Czech Republic 2015.

Juhász K. P. - Kis V.: The effect of the length of macro synthetic fibres on their performance in concrete. In: Fibre Concrete 2017. Eds: A. Kohoutková et al. Czech Republic 2017.

Krenchel, H.: Fibre spacing and specific fibre surface. In: Fibre reinforced cement and concrete. Ed.: A. Neville. The construction Press, UK 1975. 67-75.

Lee, C. - Kim, H.: Orientation factor and number of fibers at failure plane in ring-type steel fiber reinforced concrete. Cement and Concrete Research 40 (2010) 5. 810- 819.

Lee, S. C. - Cho, J. Y. - Vecchio, F. J.: Diverse Embedment Model for Steel Fiber-Reinforced Concrete in Tension: Model Development. ACI Materials Journal 108 (2011) 5. 516-525.

Maidl, B. R.: Steel Fibre Reinforced Concrete. Ernst \& Sohn, 1995.

Naaman, A. E.: A Statistical Theory of Strength for Fiber Reinforced Concrete. Doktori disszertáció, 1972.

Ng, T. S. - Foster, S. J. - Htut, T. N. S.: Fracture of Steel Fibre Reinforced Concrete - the Unified Variable Engagement Model. UNICIV Report R-460, School of Civil and Environmental Engineering, The University of New South Wales, 2012.

Oh, B. H. - Kim, J. C. - Choi, Y. C.: Fracture behavior of concrete members reinforced with structural synthetic fibers. Engineering Fracture Mechanics 74 (2007) 243-257.

Palotás L.: Siome-rendszerủ acélszál-erősítésű betoncsövek. BME Építőanyagok Tanszék tanulmánya, 1975. 
Romualdi, J. P. - Batson, G. B.: Tensile Strength of Concrete Affected by Uniformly Distributed Beams with Closely Spaced Reinforcement. ACI Journal 60 (1963) 6. 775-790.

Romualdi, J. P. - Mandel, J. A.: Tensile Strength of Concrete Affected by Uniformly Distributed and Closely Spaced Short Lengths of Wire Reinforcement. ACI Journal 61 (1964) 6. 657-672.

Sarmiento, E. V. - Zirgulis, G. - Sandbakk, S. - Geiker, M. R. - Kanstad, T.: Influence of concrete flow on fibre distribution, orientation and mechanical properties of fibre reinforced concrete. In: BEFIB2012 - Fibre reinforced concrete. Ed.: J. Barros. 2012.

Soroushian, P. - Lee, C. D.: Distribution and orientation of fibers in steel fiber reinforced concrete. $A C I$ Material Journal 87 (1990) 5. 433-439.

Stroven, P.: Methodology of modeling fiber reinforcement in concrete elements. In: Fracture Mechanics of Concrete Structures - High Performance, Fiber Reinforced Concrete, Special Loadings and Structural Applications. Ed.: B. H. Oh, et al. Korea Concrete Institute, 2010. 1418-1424.

Szabó I.: Acélhaj beton. Müszaki Könyvkiadó, Budapest 1976.

Voo, J. Y. L. - Foster, J. S.: Variable Engagement Model for the Design of Fibre Reinforced Concrete Structures. In: Advanced Materials for Construction of Bridges, Buildings, and Other Structures III. Eds: Mistry V. et al. Switzerland 2003.

Zerbino, R. - Tobes, J. M. - Bossio, M. E. - Giaccio G.: On the orientation of fibres in structural members fabricated with self compacting fibre reinforced concrete. Cement \& Concrete Composites 34 (2012) 191-200.

\title{
DETERMINING THE ORIENTATION OF STEEL AND SYNTHETIC FIBRES IN FIBRE REINFORCED CONCRETE
}

\begin{abstract}
Summary
The spread and utilization of both steel and the synthetic fibre reinforced concrete in the industry demand the constant improvement of calculation methods. Quantity of the fibres passing through the unit cross section is a relevant parameter: on one hand it gives information about the efficiency of the fibres, while on the other hand, by counting the fibres on the surface of the broken test specimen, the evenness of the fibres' mingling can be examined or dispersion of the results can be decreased. Therefore for most of the material model the initial parameter is the quantity of fibres passing through the unit cross section.

Fibres located at the fibre reinforced concrete are supposed to be mixed evenly and homogeneously while the fibre orientation is random. However, this orientation changes near the formwork as fibres become partly directional, which affects the quantity of the fibres passing through the unit cross section as well. Researchers were interested in defining this quantity even at the early examination stages of fibre reinforced concrete, so for their definition there are theoretical, semi-empirical and empirical formulas as well in literature. In the current article I will examine the changing of orientation near the formwork and I also differentiate between the rigid (steel) and flexible (synthetic) fibres. I will demonstrate new calculation methods for the quantity of fibres passing through the unit cross section that involve both the wall-effect and the stiffness of the fibres.
\end{abstract}

Keywords: fibre reinforced concrete, steel and synthetic fibres, fibres crossing the section 